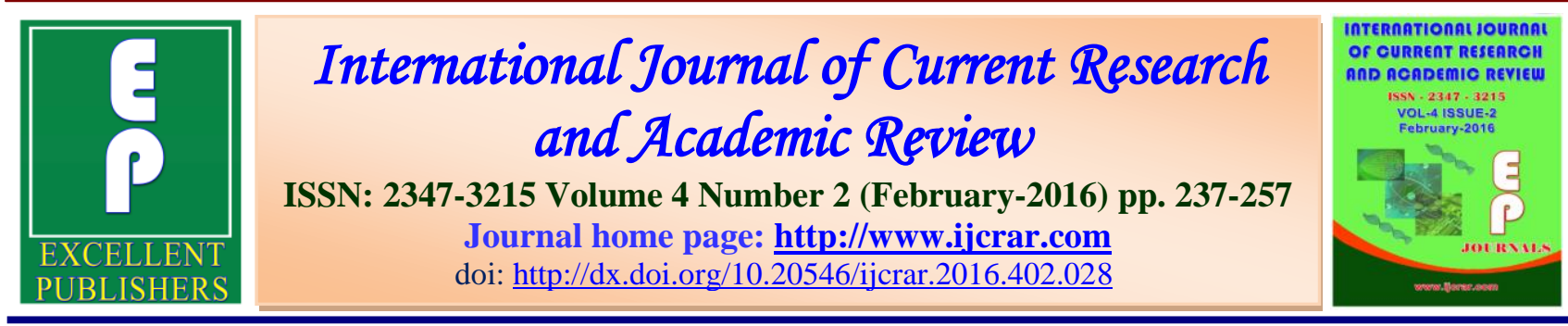

\title{
Predictive validity of mock senior school certificate examination on neco senior secondary school certificate examination scores in agricultural science in Abia state
}

\section{Madu, Aldophus ${ }^{1 *}$ and Ebere, Collins ${ }^{2}$}

${ }^{1}$ Department of Science Education, Michael Okpara University of Agriculture, Umudike, Abia State, Nigeria

${ }^{2}$ Department of Agricultural/Home Economics Education, Michael Okpara University of Agriculture, Umudike, Abia State, Nigeria

*Corresponding author

\begin{tabular}{|c|c|}
\hline KEYWORDS & $\mathbf{A} B \mathbf{B} \mathbf{T} \mathbf{R} \mathbf{A} \mathbf{C}$ \\
\hline $\begin{array}{l}\text { Predictive Validity, } \\
\text { Mock Senior School } \\
\text { Certificate } \\
\text { Examination, } \\
\text { NECO Senior } \\
\text { Secondary School } \\
\text { Certificate } \\
\text { Examination, Scores } \\
\text { in Agricultural } \\
\text { Science }\end{array}$ & 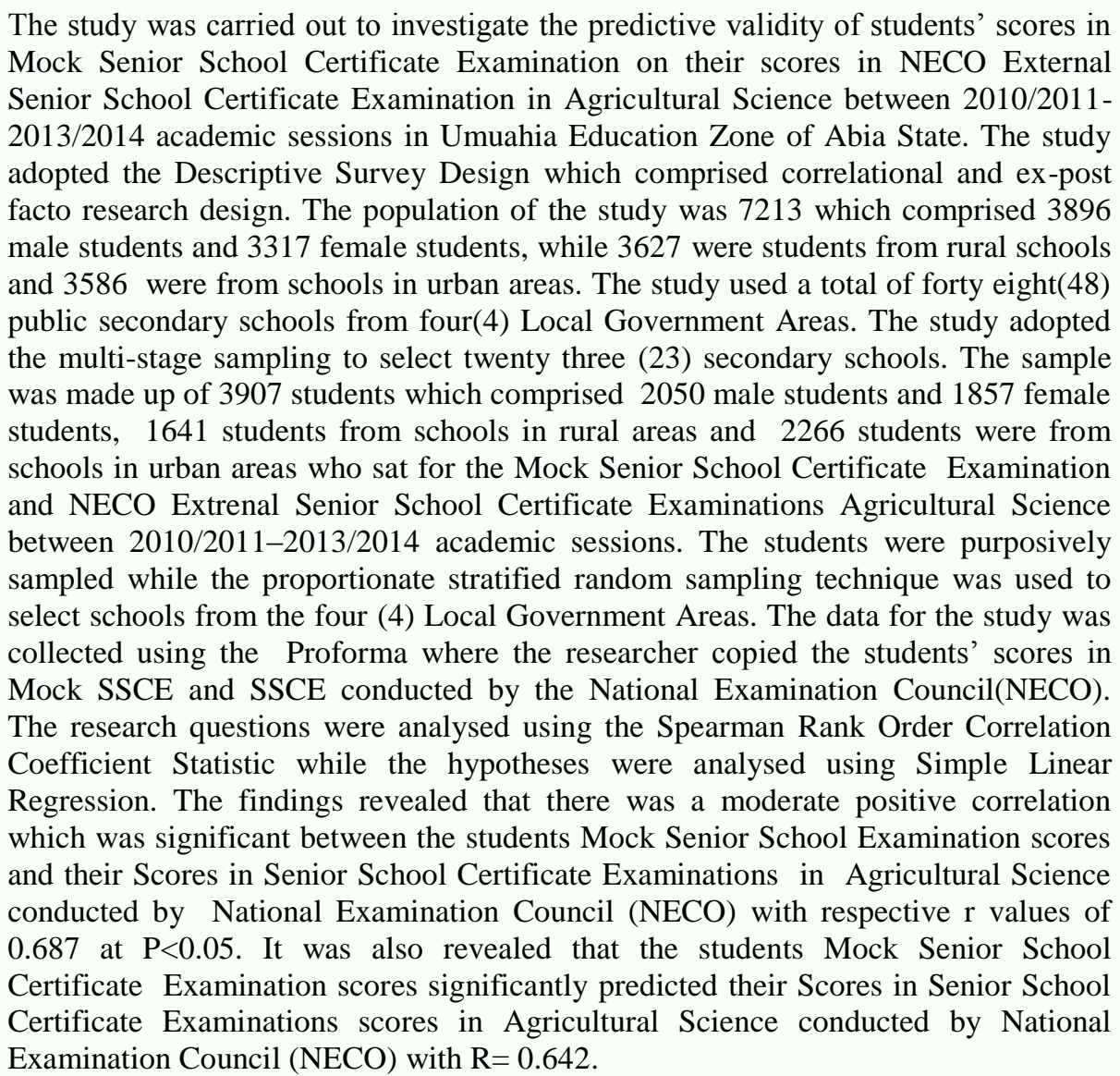 \\
\hline
\end{tabular}




\section{Introduction}

In the Nigerian educational system, achievement at any level is crowned with certification for those who successfully complete the course of study. This certification can be achieved by the administration of end of year examinations which are summative evaluations. These summative evaluations are usually in the form of examinations, Ukwuije (2012) defined examination as a measure of sample of behaviour, which is used for Certification. There are two major forms of examination taken in Nigeria and they are classified according to bodies which conduct the examination and these are internal and external examinations.

The internal examinations are conducted by various schools which include the Mock both at the Junior Secondary and Senior Secondary Schools while the external examinations are conducted by external examination bodies which include the West African Examination Council (WAEC) which conducts the West African Senior Secondary School Certificate Examination (WASSCE), National Examination Council (NECO) which conducts both the Senior Secondary School Certificate Examination and the Basic Education Certificate Examination(BECE) for all Unity schools in Nigeria. The National Business and Technical Examination Board(NABTEB), which also conducts External Senior School Certificate Examination for both business, secretariat and technical schools. The Joint Admissions and Matriculations Board (JAMB) conducts the Unified Tertiary and Matriculations Examination (Ukwuije 2012).

According to Adeyegbe (2004), these tests used by various public examinations board are often better developed than the one prepared by the teachers in the school setting. Examinations, both internal such as Mock and external such as National Examination Council Senior Secondary Certificate Examinations are used for grading and placement in the education system. This is to ensure that goals of secondary education that are spelt out in the National Policy on Education are achieved. The National Policy on Education (FRN, 2013) stipulates that secondary education has among others the following goals:

i. to provide all primary school leavers with the opportunity for education of a higher level, irrespective of sex, social status, religious or ethnic background.

ii. to provide trained manpower in the applied science, technology and commerce at sub-professional grades,

iii. to inspire students with a desire for self improvement and achievement for excellence

iv. to raise generation of people who can think for themselves, respect the views and feelings of others, respect the dignity of labour, appreciate those values specified under our broad National goals and live as good citizens.

From the fore going, Secondary education is very imperative and plays a prominent role towards National development and manpower training. According to the 9-3-4 system of education that is operational in Nigeria, the Senior Secondary Education takes three years. The Senior Secondary School runs for a period of three academic sessions. At the Senior Secondary School level, many subjects are offered; they include the arts, vocational, social sciences, commercial sciences (Nlebem, 2011). Agricultural science is one of the elective 
science subjects which students from arts, vocational and commercial can select.

Agricultural science can be defined as the science of rearing of animals and raising of crops for human consumption (Erebor, 2003). The subject is a very important subject in our society and our educational system, because of the growing influence of Agriculture in the economy of Nigeria especially in the presence of dwindling oil prices. Agriculture is the mainstay in any Nation's economic and social development (Joshua, 2007), It contributes to about 68\% of the labour force in Nigeria, as it is also the principal sources of livelihood in Nigeria (Philip et al., 2008). In spite of the vast arable land, conducive climate and different agricultural programmes, the hope of Nigeria attaining self sufficiency in food production has not been realized (FAO,2006). Due to the importance of Agriculture to the Nigerian economy, it remains one of the few subjects that is offered at Primary, Junior Secondary, Senior Secondary Schools and Tertiary institution. Agricultural science is classified as a vocational subject in the National Policy on Education (FRN, 2004). A good knowledge of Agricultural science is a pre requisite for the study of Agriculture and its allied Courses such as Agricultural Economics, Animal Science, Crop Science and Production. This importance gave rise to the objectives of Agricultural Science as stipulated in the Agricultural Science Curriculum to include, stimulating and sustaining student's interest in Agriculture, enabling students to acquire basic knowledge and practical skills, preparing students for future occupations.

In other to achieve best performance in Agricultural Science at the External Senior School Certificate Examination (SSCE), adequate preparations are given to the students prior to the External Senior School Certificate Examination. Some of these preparations include intensive coaching for the students, and sitting for the Mock Senior School Examination. According to Okoye (2006), Mock-Senior School Certificate Examination is a pre-requisite examination which prepares candidates for the final Senior School Certificate Examination. According to Nlebem (2011), the Senior School Certificate Examination is an external examination while the internal examination set after the pattern of the Senior School Certificate Examination is called the Mock Senior School Examination. The Mock Senior School Certificate Examination is therefore an examination that makes mockery of the External Senior School Certificate Examination or made to look exactly in content and cognitive requirements as the Senior School Certificate Examination (Emmanuel et al.,2011). The performance of students in Mock Senior School Certificate Examination is an important indicator or factor that may relate to overall performance of students in External Senior School Certificate Examination. The performance of students in the External Senior School Certificate Examination has not been encouraging.

This performance of students in the External Senior Secondary Certificate Examination has raised questions like, do students' performance in Mock Senior School Certificate Examination have any relationship with their scores in External Senior School Certificate Examination? To this extent the scores in External Senior School Certificate Examination should be predicted by the scores of Mock Senior School Certificate Examinations; this is because the Mock Senior School Certificate Examination is seen as an effective tool towards preparing students for external 
Examination such as the Senior School Certificate Examination. Therefore this study will evaluate how effective the Mock Senior School Certificate Examination adequately prepares students for the External Senior School Certificate Examination. This implies that a student who makes "A" grade in Mock Senior School Certificate Examination should at least make a " $B$ " or " $A$ " in the External Senior School Certificate Examination.

It therefore becomes very imperative to carry out the study "Predictive Validity of Students Scores in Mock Senior School Certificate Examination on the External Senior School Certificate Examination Scores in Agricultural Science." This will help to establish if the students' scores in Mock Senior School Certificate Examination is actually a good predictor of the criterion which is the students' scores in External Senior School Certificate Examination Agricultural Science. It will also help us to establish how well the Mock Senior School Certificate Examination is an effective assessment technique for preparing students for external Examinations such as Senior School Certificate Examination and how the predictive validity of scores in Mock Senior School Certificate Examination on the NECO External Senior School Certificate Examination is influenced by gender and school location.

According to Nkemakolam (2009) validity is referred to as the extent to which an instrument or a test measures what it is intended to measure or what it purports to measure, while Olatunji et al. (2004) defined predictive validity as the extent to which the result of a test is able to forecast performance in other related activities occurring later on. Previous studies have questioned the validity and predictive validity of teacher made test such as Mock Senior School Examination. It is believed that teacher made tests have poor or lack proper psychometric properties such as the difficulty, discrimination, distractor effectiveness, reliability and validity. Ukwuije (2012) asserted that teacher made tests do not possesses good psychometric properties. On the other hand the Mock Senior School Certificate Examination is usually conducted to prepare students for the NECO External Senior School Certificate Examination. Since these tests are said to be poor in psychometric properties, can we ascertain whether Mock-Senior School Certificate Examination scores significantly predict the NECO External Senior School Certificate Examination scores in Agricultural Science? To what extent do variables like school type, gender and school location influence predictive validity of Agricultural Science Mock-Senior School Certificate Examination scores on Senior School Certificate Examination? Can we say that those who perform well in Mock-Senior Secondary Certificate Examination could equally do well in the Senior School Certificate Examination? The outcome of this study will help to encourage intensifying efforts in preparing students using the Mock-Senior School Certificate Examination or suggest possible ways of achieving this.

Furthermore, to adopt a wholistic approach in finding the predictive validity of students' scores in Mock Senior School Certificate Examination on External Senior School Certificate Examination in Agricultural Science, it will be necessary to examine those factors which influence the performances of students in Agricultural Science. These factors include gender and school location. Studies by Salau (1999) based on gender revealed that male perform better than female in Science Subjects. Similarly, Adesoji and Kenni(2013) found out that both male and female student's performance in Mock Senior School 
Certificate Examination predicted their performance in West African Senior School Certificate Examination in Chemistry. The study of Nlebem (2011) revealed that there was a significant relationship between Mock Senior School Certificate Examination scores and the External Senior School Certificate Examination scores of female and male students, this she attributed to the fact that females now compete with the male students in various aspect of life. The study of Nlebem (2011) revealed that there was a significant relationship between student's scores in Mock Senior School Certificate Examination and NECO External Senior School Certificate Examination Biology in both urban and rural schools. In the midst of these inconsistencies of results, the present study will seek to find the Predictive Validity of Mock Senior School Examination Scores on Senior School Certificate Examination Scores in Agricultural Science based on gender of students and school location of students

Recently students are faced with the problem of writing many examinations, which include the internal and external examinations such as the Senior School Certificate Examination, Unified Tertiary and Matriculation Examination and PostUnified Tertiary and Matriculation Examination in various universities. There is the need to solve the problem of writing multiple examinations. The Senior School Certificate Examination is an achievement test used for certifying students and they guarantee student admission into higher institution, including securing job opportunities. In most cases, fears have been raised on the authenticity of the NECO External Senior School Certificate Examination because of alleged examination malpractices and the influence of factors such as gender and school location. It is then necessary for an effective model be evolved for conducting periodic checks on the predictive validity of the Mock Senior School Certificate Examination. In this regard one may ask is the Mock-Senior School Certificate Examination scores a good predictor of the NECO External Senior School Certificate Examination scores.

\section{Purpose of the Study}

The purpose of this study is to determine the predictive validity of students' scores in Mock Senior School Certificate Examination on NECO External Senior School Certificate Examination Scores in Agricultural Science. It has the following specific objectives; To

i. find out the correlationship between students Mock Senior School Certificate Examination scores and NECO External Senior School Certificate Examination scores in Agricultural Science.

ii. find out the correlationship between male students Mock Senior School Certificate Examination scores and their NECO External Senior School Certificate Examination scores in Agricultural Science.

iii. establish the correlationship between female students Mock Senior School Certificate Examination scores and their NECO External Senior School Certificate Examination scores in Agricultural Science.

iv. establish the correlationship between the Mock Senior School Certificate Examination scores of students in schools located in Rural area and their NECO External Senior School Certificate Examination scores in Agricultural Science.

v. establish the correlationship between the Mock Senior School Certificate 
Int.J.Curr.Res.Aca.Rev.2016; 4(2): 237-257

Examination scores of students in schools located in Urban area and their NECO External Senior School Certificate Examination scores in Agricultural Science.

vi. determine whether the students Mock Senior School Certificate Examination scores predict their NECO External Senior School Certificate Examination scores in Agricultural Science.

vii. determine whether the female students Mock Senior School Certificate Examination scores predict their NECO External Senior School Certificate Examination scores in Agricultural Science.

viii. determine whether the male students Mock Senior School Certificate Examination scores predict their NECO External Senior School Certificate Examination scores in Agricultural Science.

ix. determine whether the Mock Senior School Certificate Examination Scores of students in schools located in Rural areas predict their NECO External Senior School Certificate Examination scores in Agricultural Science.

x. determine whether the Mock Senior School Certificate Examination Scores of students in schools located in Urban areas predict their NECO External Senior School Certificate Examination scores in Agricultural Science.

\section{Research Questions}

The following research questions were formulated to guide the study:

1. How do students' scores in Mock Senior School Certificate Examination correlate with their scores in NECO External Senior School Certificate Examination Agricultural Science?

2. How do male students' scores in Mock Senior School Certificate Examination correlate with their scores in NECO External Senior School Certificate Examination Agricultural Science?

3. How do female students' scores in Mock Senior School Certificate Examination correlate with their scores in External Senior School Certificate Examination Agricultural Science?

4. How do Mock Senior School Certificate Examination of students in schools located in Rural area correlate with their scores inNECO External Senior School Certificate Examination Agricultural Science?

5. How do the Mock Senior School Certificate Examination of students in schools located in Urban area correlate with their scores in NECO External Senior School Certificate Examination Agricultural Science?

\section{Hypotheses}

1. The students' scores in Mock Senior School Certificate Examination Agricultural Science do not significantly predict their scores inNECO External Senior School Certificate Examination Agricultural Science.

2. The female students' scores in Mock Senior School Certificate Examination Agricultural Science do not significantly predict their scores in NECO External Senior School Certificate Examination Agricultural Science 
3. The male students' scores in Mock Senior School Certificate Examination Agricultural Science do not significantly predict their scores in NECO External Senior School Certificate Examination Agricultural Science.

4. The Mock Senior School Certificate Examination scores of students in schools located in Rural areas in Agricultural Science do not significantly predict their scores in NECO External Senior School Certificate Examination Agricultural Science.

5. The Mock Senior School Certificate Examination scores of students in schools located in Urban areas in Agricultural Science do not significantly predict their scores in NECO External Senior School Certificate Examination Agricultural Science.

\section{Research Methodology}

This chapter describes the methods and procedure adopted by the researcher. In particular, it discusses the Research Design, Area of the Study, Population of the Study, Sample and Sampling techniques, the instruments and techniques used in collecting and analyzing data.

\section{Research Design}

The Descriptive Survey Research Design which comprised Correlational and Expostfacto studies design was employed for this study. The Descriptive Survey Research Design is one directed towards determining the nature of situation as it exists at the time of the study, (Maduabum, 2004). This was because data was collected from a relatively large number of people considered to be a representative of the entire group. It comprised Correlational and Expost- facto studies design. The Correlational and Expost- facto studies design were employed to investigate the relationship that exist between the performance of students in Mock-Senior School Certificate Examination (predictor variables) and National Examination Council Senior School Certificate Examination (Criterion Variable) between 2010/2011 - 2013/2014 academic sessions. Correlational studies design are defined as studies design which are aimed at determining the relationship between two or more variables and enabling us to ascertain the extent to which variation in one variable are associated with variations in another (Maduabum). The Correlational Studies design was used in this study because the researcher is interested in finding the relationship that exists between the Mock-Senior School Certificate Examination and the NECO Senior School Certificate Examination. The latter design which is the Expost facto was used because both the cause and the effect had already occurred while the data involved in the study were as they were, when collected from their sources without any manipulation (Maduabum,). This design was adopted because the results of Mock-Senior School Certificate Examination and the NECO Senior School Certificate Examination already existed.

\section{Area of Study}

This study was conducted in Umuahia Education Zone of Abia State. Umuahia education zone comprised Secondary Schools in four Local Government Areas (L.G.A) namely, Umuahia North, Umuahia South, Ikwuano and Umunneochi. Umuahia Education Zone is bounded to the North by Anambra and Enugu State, bounded to the south by Isiala Ngwa North, to the East by Akwa-Ibom State and to the West by Imo State. The occupation of the people of 
Umuahia Education Zone are mainly farming and trading. The researchers choose the study in this zone because of his familiarity of the zone. It is also a zone that is exploring all avenues to improve students 'performance in External Senior School Certificate Examination especially in Agricultural Science. It is also an agrarian zone in Abia State and wants to promote students interest in Agriculture.

\section{Population of Study}

The accessible population of schools consisted of all the Senior Secondary School Three (3) students who sat for the External Senior School Certificate Examination conducted by the National Examination Council between 2010/2011- 2013/2014 academic sessions respectively in Umuahia Zone of Abia State, as provided by the Abia State Ministry of Education (2014).

There are a total of seven thousand two hundred and thirteen students (7213) which comprise 3896 male students and 3317 female students, 3627 from schools in rural areas and 3586 from schools in urban areas from a total of forty eight (48) Public Senior Secondary Schools which comprised of nine (9) schools located in urban areas and thirty nine (39) schools located in rural areas that have sat for the Senior School Certificate Examination conducted by National Examination Council (NECO) between 2010/2011-2013/2014 academic session respectively in Umuahia Education Zone of Abia state. The forty eight (48) schools constitute the target population, because they have attained Senior Secondary School III, offer Agricultural Science as a subject and have sat for the Senior School Certificate Examination conducted by National Examination Council (NECO) in the years under study

\section{Sample and Sampling Techniques}

The sample of Students consisted of 3907 which comprised 2050 male Students and 1857 female students, 1641 from schools in rural location and 2266 from schools in urban location who sat for the Mock-Senior School Certificate Examination and National Examination Council Senior School Certificate Examination between 2010/2011-2013/2014 academic sessions from a total of twenty three (23) schools selected for the study. The sampled students represent $54 \%$ of the population of students for the study. This was considered adequate, because Nwanna (2007) recommended even the use of $10 \%$ for a population of few thousand. (See appendix 4 for the distribution of sampled Students according to gender and schools location across the four Local Government Areas.

The multi stage sampling techniques was adopted for the study. The first stage involves the selection of Urban schools using the purposive sampling technique because they are few in numbers while the proportionate stratified sampling was used to select the Rural schools across the four Local Government Area. The Purposive sampling was used to sample the students from the schools that make up the sample schools. The sample schools comprised twenty three (23) schools in Umuahia Education zone of Abia State, which represents $48 \%$ of the school population. This was considered adequate, because Nwanna (2007) recommended even the use of $10 \%$ for a population of few thousand. The selected schools comprised of nine (9) schools from Urban Areas and fourteen (14) from Rural schools. The Urban schools were selected using the purposive sampling technique because they are few in numbers while the proportionate stratified sampling 
was used to select the Rural schools across the four Local Government Area.

This involves the listing of all the schools in Rural areas in each of the four Local Government Areas and selecting them based on proportionate stratified simple random sampling. First and foremost a sampling fraction for the selection of the number of schools in Rural areas according to the Local Government Areas was determined as follows.

$\mathrm{S} . \mathrm{F}=\frac{n}{N}$

Where SF = sampling fraction

$\mathrm{n}=$ sample size of schools

$\mathrm{N}=$ total number of schools in the four Local Government Areas

Therefore Sampling Fraction used for selecting the school located in the Rural areas in each of the local Government Area was $\frac{14}{39}=0.36$

0.36 was used to multiply all schools located in Rural areas according to Local Government Area. This was followed by listing the schools in each Local Government Area and their serial number recorded in piece of papers. The piece of papers were folded and placed in a hat and mixed thoroughly. Simple random sampling was conducted by asking one of the research assistants to pick a piece of paper at a time up to the required number of schools. The schools bearing the serial numbers picked formed the sample schools located in Rural Areas which was used for this study.

\section{Instrument for Data Collection}

The instrument for data collection was collected using a Proforma which enabled the researcher copy the students' scores in Mock-Senior School Certificate Examination and the External Senior School Certificate Examination conducted by West African Examination Council and National Examination Council Agricultural Science. The results were collected in the form of ordinal data. Both the Mock-Senior School Certificate Examination and External Senior School Certificate Examination conducted by NECO were graded using the revised stanine scores of

$\begin{array}{ll}\mathrm{A}_{1} & \text { Excellent } \\ \mathrm{B}_{2} & \text { Very Good } \\ \mathrm{B}_{3} & \text { Good } \\ \mathrm{C}_{4} & \text { Credit } \\ \mathrm{C}_{5} & \text { Credit } \\ \mathrm{C}_{6} & \text { Credit } \\ \mathrm{D}_{7} & \text { Pass } \\ \mathrm{E}_{8} & \text { Pass } \\ \mathrm{F}_{9} & \text { Fail. }\end{array}$

\section{Data Collection Procedure}

The Mock-Senior School Certificate Examination, West African Senior School Certificate Examination and National Examination Council Senior School Certificate Examination results were sourced from the examination record units of the various schools sampled using a Proforma, hence the study made use of primary data.

\section{Method of Data Analysis}

The research questions 1, 2,3,4 and 5 was answered using the Spearman Rank Order Correlation Coefficient statistic to determine 
the extent of relationship between the Mock-Senior School Certificate Examination and External Senior School Certificate Examination conducted by and National Examination Council. The relationship between Mock-Senior School Certificate Examination and NECO External Senior School Certificate Examination was answered separately using and National Examination Council Senior School Certificate Examination scores in Agricultural Science separately. The Spearman Rank Order Correlation Coefficient Statistic was used because the scores for the Mock-Senior School Certificate Examination and NECO External Senior School Certificate Examination were collected in an ordinal form.

\section{Results and Discussion}

The Spearman Rank Order Correlation Coefficient between the students' scores in Mock-Senior School Certificate Examination and National Examination Council Senior School Certificate Examination between 2010/20112013/2014 Agricultural Science shows a moderate positive correlation with an $r$ value of 0.687 which is significant $(p<0.05)$ at 0.01 level of significance.

Research Question Two: How do male students' scores in Mock Senior School Certificate Examination correlate with their scores in External Senior School Certificate Examination Agricultural Science?

The Spearman Rank Order Correlation Coefficient between the male students Mock-Senior School Certificate Examination and their National Examination Council Senior School Certificate Examination (NECOSSCE) scores in Agriculture Science shows a very highly positive correlation with an r-value of 0.964 which is significant $(\mathrm{p}<0.05$.) at 0.01 level of significance.

Research Question Three: How do female students' scores in Mock Senior School Certificate Examination correlate with their scores in Senior School Certificate Examination Agricultural Science?

The Spearman Rank Order Correlation Coefficient between the female students scores in the Mock Senior School Certificate Examination and their National Examination Council Senior School Certificate Examination (NECOSSCE) shows a very high positive correlation with an r-value of 0.970 which is significant $(p<0.05)$ at 0.01 level of significance.

Research Question Four: How do Mock Senior School Certificate Examination scores of students in schools located in Rural areas correlate with their scores in External Senior School Certificate Examination Agricultural Science?

The Spearman Rank Order Correlation Coefficient between the students' scores in Mock Senior School Certificate Examination of schools located in Rural areas and their scores in National Examination Council Senior School Certificate Examination (NECOSSCE) shows a high positive correlation with an $\mathrm{r}$ value of 0.781 which is significant $(p<0.05)$ at 0.01 level of significance.

Research Question Five: How do the Mock Senior School Certificate Examination scores of students in schools located in Urban areas correlate with their scores in External Senior School Certificate Examination Agricultural Science?

The Spearman Rank Order Correlation Coefficient between the students' scores in 
Int.J.Curr.Res.Aca.Rev.2016; 4(2): 237-257

Mock Senior School Examination and the National Examination Council Senior School Certificate Examination (NECOSSCE) shows a moderate positive correlation with an r-value of 0.640 which is significant $(\mathrm{p}<0.05$.) at 0.01 level of significance.

Hypothesis one: The student scores in Mock-Senior School Certificate Examination do not significantly predict their scores in External Senior School Certificate Examination in Agricultural Science.

Data in table 6 do reveal that the R. value of 0.642 which implies that there is a moderate positive Pearsons Product Moment Coefficient Correlation between the Mock Senior School Certificate Examination and the NECOSSCE Agricultural science between 2010/2011 - 2013/2014 academic sessions. Also it also shows an $\mathrm{R}^{2}$ of 0.42 which is the Coefficient of Determination. This implies that $41.2 \%$ of the NECOSSCE Agricultural science is explained by or accounted for by the Mock Senior School Certificate Examination. The regression equation is useful for making prediction since the $\mathrm{R}^{2}=0.412$ which indicates positive value.

Data in table 7 shows an F- value of 2733.730 and p-value of 0.000 since the pvalue of 0.000 is less than 0.05 , we shall reject the null hypothesis which states that student scores in Mock Senior School Certificate Examination Agricultural do not significantly predict their scores in NECO SSCE Agricultural science between 2010/2011 - 2013/2014 academic sessions. Therefore we accept the alternate hypothesis which implies that student scores in Mock Senior School Certificate Examination significantly predict their scores in
NECOSSCE Agricultural science between 2010/2011 - 2013/2014 academic sessions.

Data in table 8 establishes the prediction as the unstandardized coefficient values of $B$ are 2.070 and 0.686 for the slope and the intercept, therefore the prediction equation is NECO SSCE $=2.070+0.686 \mathrm{MOCK}$ SSCE. It also reveals that at 0.05 level of significance with a p-value of 0.000 which is less than 0.05. It implies that the student scores in MOCK SSE Agricultural science significantly predict scores in NECO SSCE Agricultural science between 2010/20112013/2014 academic sessions.

Hypothesis Two: The female student scores in Mock Senior School Certificate Examination in Agricultural science do not significantly predict their scores in External Senior School Certificate Examination Agricultural science.

Data in table 9 Show an $R$ value of 0.964 which implies that there is almost a perfect Pearson's Products Moment Correlation Coefficient between the female students in MOCK SSCE and their scores in NECO SSCE between 2010/ 2011-2013/2014 session. It also shows an $\mathrm{R}$ square of 0.929 which is the Coefficient of Determination, this implies that $92.9 \%$ of the NECO SSCE Agricultural science is explained or accounted for by the Examination. The shows that the regression equation for the female scores appear to be very useful for making prediction since the $\mathrm{R}^{2}$ value of 0.964 is close to 1 .

Data in table 10. show an F-value of 23323.461 and p-value of 0.000 , since the pvalue of 0.000 is less than 0.05 , we shall reject the null hypothesis which states that students scores in Mock Senior School Certificate Examination Agricultural science do not significantly predict their scores in 
NECOSSCE Agricultural science between 2010/2011-2013/2014 academic sessions. Therefore we accept the alternate hypothesis which implies that female students' scores in Mock Senior School Certificate Examination significantly predicts their scores in NECOSSCE Agricultural science between 2010/2011-2013/2014 academic sessions.

Data in table 11establishes the prediction or regression equation as the unstandardized coefficient values of $\mathrm{B}$ are 0.503 and 1.002 for the slope and the intercept respectively. Therefore the prediction equation for female scores is NECOSSCE $=0.503+1.002$ Mock Examination. It also reveals that at 0.05 level of significance with a p-value of 0.000 which is less than 0.05 , this implies that female student scores in MOCK SSCE Agricultural science significantly predicts their scores in WAEC SSCE Agricultural science between 2010/2011 - 2013/2014 academic sessions.

Hypothesis Three: The male student scores in Mock Senior School Certificate Examination in Agricultural science do not significantly predict their scores in Senior School Certificate Examination Agricultural Science.

Data in table 12 show an $\mathrm{R}$ value of 0.964 which implies that there is almost a perfect Pearson's Products Moment Correlation Coefficient between the male students in Mock Senior School Certificate Examination and their scores in NECOSSCE between 2010/2011-2013/2014 academic sessions. It also shows an $\mathrm{R}$ square of 0.929 which is the Coefficient of Determination. This implies that $92.9 \%$ of the NECO SSCE Agricultural science is explained or accounted for by the Mock Senior School Examination. The shows that the regression equation for the male scores appear to be very useful for making prediction since the $R^{2}$ value of 0.964 is close to 1 .

Data in table 13 Show an F-value of 26706.980 and $p$-value of 0.000 , since the $p$ value of 0.000 is less than 0.05 , we shall reject the null hypothesis which states that students' scores in Mock Senior School Certificate Examination Agricultural science do not significantly predict their scores in NECOSSCE Agricultural Science between 2010/2011-2013/2014 academic sessions. Therefore we accept the Alternate hypothesis which implies that male students' scores in Mock Senior School Certificate Examination significantly predicts their scores in NECOSSCE Agricultural Science between 2010/2011-2013/2014 academic sessions.

Hypothesis Four: The students' scores in Mock Senior School Certificate Examination of students from schools located in Rural areas do not significantly predict their scores in the External Senior School Certificate Examination Agricultural Science.

Data in table 4.25 Shows an $\mathrm{R}$ value of 0.764 which implies that there is almost a Perfect Pearson's Products Moment Correlation Coefficient between the Mock Senior School Certificate Examination scores of student in schools located in Rural areas and their scores in NECOSSCE between 2010/2011-2013/2014 session. It also shows an $\mathrm{R}$ square of 0.583 which is the Coefficient of Determination. This implies that $58.3 \%$ of the NECOSSCE Agricultural Science is explained or accounted for by the Mock Senior School Certificate Examination. The shows that the regression equation for the scores of student in schools located in Rural areas appear to be very useful for making prediction since the $\mathrm{R}^{2}$ value of 0.583 is close to 1 . 
It was also indicated that there was a moderate positive correlation which was significant between the student scores in Mock Senior School Certificate Examination and the National Examination Council Examination between 2010/20112013/2014 academic sessions. This finding is in agreement with the findings of Nlebem (2011) who found out that there is a significant relationship between Mock Senior School Examination scores and the Senior School Certificate Examination score in Biology.

The reason for the moderate positive correlation is not far fetched since the Mock Senior School examination is conducted to prepare candidates for the Senior School Certificate Examination. Corroborating this Okoye (2006) asserts that the Mock Senior School Certificate Examination is a prerequisite examination which prepares candidates for final school examination which is the NECO External Senior School Certificate Examination. The practical implication of this is that, a student who performs well in Mock Senior School Certificate Examination should also perform well in the final school Examination which is the NECO External Senior School Certificate Examination.

The findings from the analyses of research question two also show that there was a very high positive correlation which was significant between male students scores in Mock Senior School Certificate Examination and External Senior School Certificate Examination conducted by National Examination Council. This is in agreement with the findings of Okoye (2006) and Nlebem (2011) who in separate occasions revealed that there was significant relationship between the male student score in Mock-Senior School Certificate Examination and NECO External Senior School Certificate Examination.
The finding from the analysed research question three shows that there was a very high positive correlation which was significant between the female student scores in Mock Senior School Certificate Examination and their scores in External Senior School Certificate Examination Agricultural Science conducted by National Examination Council between 2010/2011$2013 / 2014$ academic session. This is in agreement with the findings of Nlebem (2011) who found out that there is a significant relationship between females score in Mock Senior School Certificate Examination and NECO External Senior School Certificate Examination similarly Adesoji (2013) also find out that female students score in Mock Senior School Certificate Examination significantly correlated with their NECO External Senior School Certificate Examination.

The findings from the analyses of research question four show that there was a high positive correlation which was significant between the Mock Senior School Certificate Examination scores of students in schools located in rural area and their score in Senior School Certificate Examination Agricultural Science conducted by National Examination Council (NECO) between 2010/20112013/2014 academic session. The practical implication of this finding is that students from schools located in Rural Areas are doing favourably well in academics and should not be neglected

The findings from research question five also show that there was a moderate positive correlation which was significant between Mock Senior School Certificate Examination scores of students in schools located in Urban areas and their scores in External Senior School Certificate Examination Agricultural Science conducted by National Examination between 2010/2011- 2013/2014 academic session. 
Int.J.Curr.Res.Aca.Rev.2016; 4(2): 237-257

Table.1 Spearman Rank Order Correlation Coefficient of Students' Scores in Mock Senior School Certificate Examinations and Scores in National Examination Council Senior School Certificate Examinations (Necossce) in Agricultural Science between 2010/2011-2013/2014 Academic Sessions

\begin{tabular}{lll}
\hline $\begin{array}{l}\text { Independent variable } \\
\text { MOCK SSCE }\end{array}$ & $\begin{array}{l}\text { Independent variable } \\
\text { MOCK SSCE }\end{array}$ & $\begin{array}{l}\text { Dependent variable } \\
\text { NECO SSCE }\end{array}$ \\
\hline & 1.000 & $0.687^{* *}$ \\
& & 0.000 \\
$\mathrm{~N}$ & 3907 & 3907 \\
Dependent Variable & $0.687^{* *}$ & 1.000 \\
NECO SSCE & 0.000 & \\
$\mathrm{~N}$ & 3907 & 3907 \\
** Significant at 0.01 level $(2$-tailed) $\mathrm{P}<0.05$ &
\end{tabular}

Table.2 Spearman Rank Order Correlation Coefficient between Mock- Senior School Certificate Examination Scores of Male Students and their External Senior School Certificate Examination (Ssce) Scores of in Agricultural Science between 2010/2011 - 2013/2014 Academic Sessions

\begin{tabular}{llll}
\hline & MOCK & NECO \\
\hline Spearman's rho & Mock Correlation coefficient & 1.000 & $.946^{* *}$ \\
& Sig (2-tailed) & & .000 \\
& N & 2050 & 2050 \\
WAEC Correlation coefficient & $.971^{* *}$ & $.986^{* *}$ \\
Sig (2-tailed) & .000 & .000 \\
N & 2050 & 2050 \\
NECO Correlation coefficient & $.964^{* *}$ & 1.000 \\
Sig (2-tailed) & .000 & \\
& & 2050 & 2050 \\
\hline
\end{tabular}

** Correlation is significant at the 0.01 level (2-tailed). $\mathrm{p}<0.05$

Table.3 Spearman Rank Order Correlation Coefficient of Female Students' Scores in Mock Senior School Certificate Examination and their External Senior School Certificate Examination (Ssce) Scores in Agricultural Science between 2010/2011 - 2013/2014 Academic Sessions

\begin{tabular}{llll}
\hline & MOCK & NECO \\
\hline Spearman's rho & Mock Correlation coefficient & 1.000 & $.970^{* *}$ \\
& Sig (2-tailed) & 1857 & .000 \\
N & $.991^{* *}$ & $.972^{* *}$ \\
WAEC Correlation coefficient & .000 & .000 \\
Sig (2-tailed) & 1857 & 1857 \\
N & $.970^{* *}$ & 1.000 \\
Mock Correlation coefficient & .000 & \\
Sig (2-tailed) & 1857 & 1857 \\
N & & \\
\hline
\end{tabular}

** Correlation is significant at the 0.01 level (2-tailed). $\mathrm{p}<0.05$ 
Int.J.Curr.Res.Aca.Rev.2016; 4(2): 237-257

Table.4 Spearman Rank Order Correlation Coefficient of the Students' Scores in Mock Senior School Certificate Examination Located in Rural Areas and their Scores in External Senior School Certificate Examination (Ssce) in Agricultural Science between 2010/2011 - 2013/2014 Academic Sessions

\begin{tabular}{llll}
\hline & & MOCK & NECO \\
\hline Spearman's rho & Mock Correlation coefficient & 1.000 & $.781^{* *}$ \\
& Sig (2-tailed) & & .000 \\
N & 1641 & 1641 \\
WAEC & Correlation & $.792^{* *}$ & $.715^{* *}$ \\
& coefficient & & \\
Sig (2-tailed) & .000 & .000 \\
N & 1641 & 1641 \\
Mock Correlation coefficient & .781 & 1.000 \\
Sig (2-tailed) & .000 & \\
N & 1641 & 1641 \\
\hline ** Correlation is significant at the 0.01 level (2-tailed) p<0.05 & &
\end{tabular}

Table.5 Spearman Rank Order Correlation Coefficient of the Students' Scores in Mock Examination of Schools Located in Urban Areas and their Scores in Senior School Certificate Examination (Ssce) Agricultural Science between 2010/2011 - 2013/2014 Academic Sessions

\begin{tabular}{llll}
\hline & & MOCK & NECO \\
\hline Spearman's rho & Mock Correlation coefficient & 1.000 & $.640^{* *}$ \\
& Sig (2-tailed) & & .000 \\
& N & 2266 & 2266 \\
WAEC Correlation coefficient & $.640^{* *}$ & $.667 * *$ \\
Sig (2-tailed) & 0.000 & 0.000 \\
N & 2266 & 2266 \\
NECO Correlation coefficient & $.640^{* *}$ & 1.000 \\
Sig (2-tailed) & .000 & \\
N & 2266 & 2266 \\
\hline ** Correlation is significant at the 0.01 level (2-tailed). p $<0.05$ & &
\end{tabular}

Table.6 Summary of Regression Analysis of Students' Scores in Mock Senior School Certificate Examination Agricultural Science in Predicting their Scores in National Examination Council Senior School Certificate Examination (Necossce) Agricultural Science between 2010/20112013/2014 Academic Sessions

\begin{tabular}{lllll}
\hline Model & R & R Square & Adjusted Rsquare & Standard error of the Estimate \\
\hline 1 & .642 & .412 & .412 & 1.427 \\
\hline Predictors: (constant), Mock & & &
\end{tabular}


Table.7 Summary of Regression in Anova Showing the Prediction of National Examination Council Senior School Certificate Examination (Necossce) by their Score in Mock Senior School Certificate Examination in Agricultural Science between 2010/2011 - 2013/2014 Academic Sessions

\begin{tabular}{llllll}
\hline Model & Sum of squares & Df & Mean square & F & Sig. \\
\hline Regression & 5564.457 & 1 & 5564.457 & 2733.730 & 0.000 \\
Residual & 7948.555 & 3905 & 2.035 & & \\
Total & 13513.012 & 3906 & & & \\
\hline
\end{tabular}

Dependent Variables: NECO

Predictors: (Constant), Mock

Table.8 Summary of the Coefficient Value of the Students' Scores in Mock-Senior School Certificate Examination Predicting their Scores in National Examination Council Senior School Certificate Examination Agricultural Science between 2010/2011 - 2013/2014 Academic Sessions

\begin{tabular}{llllll}
\hline Model & B & $\begin{array}{l}\text { Unstandardised } \\
\text { coefficient } \\
\text { Standard } \\
\text { Error }\end{array}$ & $\begin{array}{l}\text { Standard } \\
\text { Coefficients } \\
\text { Beta }\end{array}$ & T & Sig. \\
& & & & \\
\hline (Constant) & 2.070 & 0.077 & .642 & 27.046 & 0.000 \\
Mock & .686 & 0.013 & & 52.285 & 0.000 \\
\hline
\end{tabular}

Dependent Variable: NECO. $=$ Regression or Prediction NECO SSCE $=2.070+0.686$ Mock Senior School Examination

Table.9 Summary of Regression Analysis of Female Students' Scores in Mock Senior School Certificate Examination Agricultural Science Predicting their Scores in National Examination Council Senior School Certificate Examination(Necossce) Agricultural Science between 2010/2011 - 2013/2014 Academic Sessions

\begin{tabular}{lllll}
\hline Modl & R & R Square & $\begin{array}{l}\text { Adjusted } \\
\text { R }\end{array}$ & $\begin{array}{l}\text { Standard Error of the } \\
\text { Estimate }\end{array}$ \\
\hline 1 & $.964^{\mathrm{a}}$ & .929 & .929 & .51079 \\
\hline
\end{tabular}

Table.10 Summary of Regression in Anova Showing the Prediction of Female Students' Scores in National Examination Council Senior School Certificate Examination (Necossce) on Agricultural Science by the Mock-Senior School Certificate Examination between 2010/2011 2013/2014 Academic Sessions

\begin{tabular}{llllll}
\hline Model & Sum of squares & Df & Mean square & F & Sig. \\
\hline Regression & 6346.176 & 1 & 6346.176 & 24323.461 & $.000^{\mathrm{b}}$ \\
Residual & 483.984 & 1855 & .261 & & \\
Total & 6830.159 & 1856 & & & \\
\hline Det & & & & & \\
\hline
\end{tabular}

Dependent Variable: NECO

Predictors (Constant), Mock 
Int.J.Curr.Res.Aca.Rev.2016; 4(2): 237-257

Table.11 Summary of Coefficient Values of Female Students' Scores in Mock Senior School Certificate Examination Predicting their Scores in National Examination Council Senior School Certificate Examination between 2010/2011 - 2013/2014 Academic Sessions

\begin{tabular}{llllll}
\hline Model & B & $\begin{array}{l}\text { Unstandardised } \\
\text { coefficient } \\
\text { Standard error }\end{array}$ & $\begin{array}{l}\text { Standardised } \\
\text { Coefficients } \\
\text { Beta }\end{array}$ & T & Sig. \\
\hline (Constant) & .503 & .036 & & 13.945 & .000 \\
Mock & 1.002 & .006 & .964 & 155.960 & .000 \\
\hline
\end{tabular}

Dependent Variable: NECO

Regression or Prediction Equation: NECOSSCE $=0.503+1.002$ Mock Examination

Table.12 Summary of Regression Analysis of Male Student Scores in Mock Senior School Certificate Examination Agricultural Science Predicting their Scores in National Examination

Council Senior School Certificate Examination(Necossce) Agricultural Science between 2010/2011 - 2013/2014 Academic Session

\begin{tabular}{lllll}
\hline Model & R & R Square & Adjusted R square & Standard error of the Estimate \\
\hline 1 & .964 & .929 & .978 & .48135 \\
\hline Predictors: (Constant). Mock & & &
\end{tabular}

Table.13 Summary of Regression in Anova Showing the Prediction of Male Students' Scores in National Examination Council Senior School Certificate Examination (Necossce) on Agricultural Science by the Mock Senior School Certificate Examination between 2010/2011 2013/2014 Academic Sessions

\begin{tabular}{llllll}
\hline Model & Sum of squares & Df & Mean square & F & Sig. \\
\hline Regression & 6187.880 & 1 & 6187.880 & 26706.980 & .000 \\
Residual & 474.512 & 2048 & .232 & & \\
Total & 6662.392 & 2049 & & & \\
\hline Detal & & & & & \\
\hline
\end{tabular}

Dependent Variable: NECO

Predictors (Constant), Mock

Table.14 Summary of Coefficient Values of Male Students' Scores in Mock Senior School Certificate Examination Predicting their Scores in National Examination Council Senior School

Certificate Examination (Necossce) between 2010/2011 - 2013/2014 Academic Sessions

\begin{tabular}{llllll}
\hline Model & B & $\begin{array}{l}\text { Unstandardised } \\
\text { coefficient } \\
\text { Standard error }\end{array}$ & $\begin{array}{l}\text { Standardised } \\
\text { Coefficients } \\
\text { Beta }\end{array}$ & t & Sig. \\
\hline (Constant) & -.350 & 0.040 & & -.8 .744 & .000 \\
Mock & 1.085 & 0.007 & .964 & 163.423 & .000 \\
\hline
\end{tabular}

Dependent Variable: NECO

Regression or Prediction Equation $=$ NECOSSCE $=-0.350+1.085$ Mock Examination 
Table.15 Summary of Regression Analysis of Scores Students' in Schools Located in Rural Areas in Mock Senior School Examination Agricultural Science Predicting their Scores in National Examination Council Senior School Certificate Examination Agricultural Science between 2010/2011 - 2013/2014 Academic Sessions

\begin{tabular}{lllll}
\hline Model & R & R Square & Adjusted R & Standard Error of the Estimate \\
\hline 1 & $.764^{\mathrm{a}}$ & .583 & .583 & 1.08173 \\
\hline Predictors: (Constant), Mock & & &
\end{tabular}

However, the correlation between the Mock Senior School Certificate Examination scores is the same between West African Senior School Certificate Examination and the National Examination Council Senior School Certificate Examination. This is in agreement with the findings of Nlebem (2011) who revealed there was a significant relationship between Mock Senior School Certificate Examination scores and External Senior School Certificate Examination score of students in Urban school location .The practical implication of this finding is that students from schools located in Urban Areas are doing well as excepted since most of them are in good public schools that are well equipped with adequate infrastructure and good teachers that will aid their academic success

The findings from hypothesis one shows that students' scores in the Mock Senior School Certificate Examination Agricultural Science predicted students' scores in the External Senior School Certificate Examination Agricultural Science conducted by NECO. The findings are in agreement with Adesoji \& Kenni (2013) who found that Mock Examination results could be used to predict performance of Students in the Senior School Certificate Examination, hence the practical implication of this finding is that it has been established that the student scores in Mock Senior School Certificate Examination can be used to predict students score in the External Senior School Certificate Examination conducted by WAEC and NECO in other subjects.
The prediction of the students' scores in external senior school certificate examination agricultural science by their scores in mock senior school certificate examination in agricultural science based on gender

The findings from hypothesis two shows that the female student scores in the Mock Senior School Certificate Examination Agricultural Science predicted their scores in the External Senior School Certificate Examination conducted. This was indicated as the female student score in Mock Senior School Certificate Examination predicted their scores in the External Senior School Certificate Examination conducted by National Examination Council respectively. Hence the practical implication of these findings are that it has been established that the male students scores in Mock Senior School Certificate Examination can be used to predict students score in the Senior School Certificate Examination conducted by NECO

The findings from hypothesis three also shows that male student score in Mock Senior School Certificate Examination predicted their scores in Senior School Certificate Examination conducted by National Examination Council respectively. Hence the practical implication of these findings are that it has been establish that the male student scores in Mock Senior School Certificate Examination can be used to predict students score in the External Senior School Certificate Examination conducted by NECO and it is influenced by gender as it 
predicted the scores of both female and male students. The findings is in agreement with the findings of Adesoji and Kenni (2013) that male students performance in Mock Senior School Certificate Examination predicted their performance in West African Senior School Certificate Examination. Similarly Nlebem (2011) found out that the prediction of the External Senior School Certificate Examination by the Mock Senior School Certificate Examination has nothing to do with gender in Biology.

The findings from the analysed hypothesis four shows that the Mock Senior School Certificate Examination scores in Agricultural Science of students in schools located in Rural area predicted their score in the External Senior School Certificate Examination conducted by National Examination Council respectively. The findings are in agreement with Nlebem (2011) who reported that there was a significant relationship between the Mock Senior School Certificate Examination score and Senior School Certificate Examination in Biology of students Located in Rural areas.

The analyses of hypothesis five also show that Mock Senior School Certificate Examination scores of students located in schools in Urban areas significantly predicted their scores in National Examination Council Senior School Certificate Examination Agricultural Science. The findings are in agreement with the findings of Nlebem (2011) who reported that there was a significant relationship between the Mock Senior School Certificate Examination score and Senior School Certificate Examination in Biology of students Located in Urban areas. The practical implication of these findings include that Urban schools do possess very good academic qualities which enhance their academic performance It could also be that since the study was carried out in Government owned school, it can be that the teachers in Urban schools are committed to their teaching profession.

\section{Conclusion}

There was a positive correlation which was significant between the students' MockSenior School Certificate Examination scores and their scores in the External Senior School Certificate Examination Agricultural Science conducted by the National Examination Council between 2010/2011-2013/2014 academic sessions. The correlation between the students' Mock Senior School Certificate Examination scores and their Scores in the External Senior School Certificate Examination Agricultural Science conducted by the and National Examination Council based on gender and school location between 2010/2011-2013/2014 academic sessions were positive and significant.The students' scores in Mock Senior School Certificate Examination was a good predictor of their scores in External Senior School Certificate Examination in Agricultural Science conducted by the National Examination Council between 2010/2011-2013/2014 academic sessions. The students' scores in Mock Senior School Certificate Examination was a good predictor of their scores in External Senior School Certificate Examination Agricultural Science conducted by the and National Examination Council based on gender and their school location between 2010/2011-2013/2014 academic sessions.

Finally, the Mock Senior School Certificate Examination becomes a very good assessment tool for preparing students for External Senior School Certificate Examination conducted by the National Examination Council. 


\section{References}

Abia State Ministry of education (2013). Statistic of education. Umuahia, Department of planning, research and statistics.

Abia State Secondary Education Management Board (2014). Statistic of education. Umuahia, Department of planning, research and statistics.

Adesoji, F.A.\& Kenni, A.M. (2013). Continuous assessment, mock results and gender as predictors of academic performance of chemistry students in WASSCE and NECO examinations in Ekiti stat: Journal of international educational studies. Vol. 6(7), 1 - 8 .

Adeyegbe, S.O. (2004). Research into STM curriculum and school examination in Nigeria. The state of the proceedings of the STAN annual conference.

Emmanuel, E.A., Peter, O.A. \& Christopher, .O.(2011). Some Nigerian student's performance in practical an theoretical chemistry tests as predictors of their performance in MOCK-SSCE chemistry examination. Journal of Science researches.3(12), 30-37

Erebor, O. (2003).Compressive agricultural science for senior secondary schools. Benin.:A Johnson Publisher Ltd.

Federal Republic of Nigeria (2004).National policy on education, Lagos: NERDC, press.

Federal Republic of Nigeria, (2013).National Policy on Education ( $4^{\text {th }}$ ed.). NERDC, press

Food \& Agricultural Organization (2006). Addressing the global food crises, key trade investment and commodity policies ensuring sustainable food security and alleviating poverty.

Joshua, S.D. (2007). Attitudinal disposition of seminar secondary school students towards agriculture in Maiduguri metropolitan Borno State. Medwell Agricultural journal. 3(2): 120 - 124.

Maduabum, M.A. (2004). Fundamentals of education research. Owerri: Versatile Printers..

Nkemakolam, E. (2003). Taxanomy of educational measures. In B.G. Nworgu (Ed): Educational measurement and education: theory and practice. Revised edition Nsukka: University Trust publishers. $66-83$.

Nkemakolam, E.O (1995). Designing and conduction research in education. Owerri: CANUS Publishers Nigeria Limited.

Nkemakolam, E.O, Igbokwe U.O \& Mkpa, N.D (1997). Statistics in Education, Fundamental Concepts and Procedure. Owerri: CANUS Publishers Nigeria Limited.

Nkemakolam, E.O. (2000). Measurement in Education: An Introduction. Owerri: Barloz Publishers Limited.

Nkemakolam, E.O. (2009). Measurement in Education: An introduction: Enugu Jibaco Publishers.

Nlebem, F.J. (2011). Predictive validity of mock SSCE scores on senior school certificate of biology in Umuahia education zone of Abia state. Unpublished M.Sc Thesis. Abia State university. Uturu.

Nwanna, O.C.(2007) Educational measurement for teachers. Lagos:

Thomas Nelson and Sons Press.

Okoye, L. (2006).“Attitude and practices of senior school teacher", Unpublished M.Ed dissertation University of Nigeria, Nsukka.

Olatunji, S.O., Akanwa, U.N. \& Nwahunanya, C.I. (2004). Measurement and evaluation of learning outcomes. Lagos: Naphtali prints limited.

Olatunji, S.O.,Akanwa, U.N. and Nwahunnaya, C.I. (2004).Measurement 
and Evaluation of learning outcomes. Lagos: Naphtali prints: A division of HG Support Nigeria Limited.

Olorundare, A.S. (2014). Theory into practice: beyond surface curriculum in science. $147^{\text {th }}$ Inaugural lecture of the University of Ilorin, p 26. $22^{\text {nd }}$ May, 2014

Philip, D., Nkonya, E., Render, J. \& Oni, A.O. (2008). "Constraint to increasing agricultural productivity in Nigeria": Nigeria strategy support programme brief. No 4 IFPRI (International food policy research institute).
Salau, M.O. (1999). Comparative effects of attending single sex and co-educational secondary schools on the female students achievement in mathematics. In: B. Olanitemi (ed). Proceeding of science teachers association of Nigeria, Ibadan: Heinemann Education Book.

Ukwuije, R.P.I. (2012). Educational assessment: A sine qua non for quality education. $83^{\text {rd }}$ inaugural lecture. University of Port Harcourt. Port Harcourt.

\section{How to cite this article:}

Madu, Aldophus and Ebere, Collins. 2016. Predictive validity of mock senior school certificate examination on neco senior secondary school certificate examination scores in agricultural science in Abia state. Int.J.Curr.Res.Aca.Rev. 4(2): 237-257.

doi: http://dx.doi.org/10.20546/ijcrar.2016.402.028 